\title{
PROSES DISEMINASI CORE SAMPLER KEPADA PETANI TEBU RAKYAT DI PG BUNGAMAYANG
}

\author{
Trikuntari Dianpratiwi ${ }^{1)}$, Triantarti $^{1)}$, Syukur H.K.' \\ ${ }^{1)}$ Pusat Penelitian dan Perkebunan Gula Indonesia (P3GI) \\ email: trikuntari.dianpratiwi@gmail.com \\ ${ }^{2)}$ Pabrik Gula Cintamanis (Alumni Faperta UNS 1983)
}

\begin{abstract}
Core sampler (CS) is a tool to get indivual cane sample on the truck to determined rendement. Dissemination process of CS in Bungamayang SF on 2014 had focussed by: (1) application concept of individual system by determine the CS on first step (transition step), and (2) socialization to cane farmer about awareness of individual rendement system, to get the cane farmers responses to determie individual rendement by CS. The aim of the dissemination is do socialization to the farmer about rendement determine system by CS. The steps of the socialization are socialization of rendement determine system by CS to SF's staff and cane farmers before milling season; to set the application concept of CS determine rendement individual system; assistance and evaluation. Socialization had done to the cane farmers at Bungamayang SF, the responses had measured by quesionare at step socialization and had analyzed descriptifly. The number of truck had evaluated are 4.947. The meeting with farmer group coordinator, staff of agricultural division, and managers of pabrikasi agree that determine of CS individual rendement system had applicated as base of payment to farmer at 2014 milling season. The 62,64\% of respondent agreed with rendement that they reach, because corresponding with cane agricultural that they done, the figure of cane had been harvested, and the rendement is higher than milling season before. Rejection of CS's rendement is 37,36\%, because they feel that they was done the good agricultural and they know that the miller often trouble. The way of the farmer group chairman deliver explanation about rendement was correct: to motivate cane farmer to revise agricultural so that reach higher rendement $(38,49 \%)$ and rendement fix to the quality of cane $(22,64 \%)$. The result of socialization show that cane farmer at Bungamayang SF know the fuction of CS, the work of CS, and CS system is worthy to solve the problem of rendement measurement.
\end{abstract}

Keywords: Core Sampler, farmer group, individual rendement, payment base, responses, socialization,

\section{PENDAHULUAN}

Petani tebu dikatakan oleh Mosher, A.T, 1984, sebagai jurutani yang berperanan membudidayakan tanaman, untuk mendapatkan hasil bermanfaat, pengelolaan mencakup pikiran yang didorong kemauan, serta pengambil keputusan. Pembinaan dan penyuluhan kepada para petani menstimulasi petani berpola pikir maju, bersedia mengadopsi teknologi dan masarkan produk. Petani menggunakan perhitungan-perhitungan produksi pertanian dan faktor-faktor produksi yang digunakan secara cermat (Kartasapoetra, dkk, 1986). Persoalan di negara berkembang termasuk Indonesia, tingkat aplikasi dan penguasaan teknologi bidang pertanian masih rendah (Arifin, Bustanul, 2004).

Dalam budidaya tebu, petani dihadapkan pada rendemen yang mencerminkan kualitas tebu ke pabrik gula. Oleh sebab itu pengukuran rendemen harus dilakukan secara akurat, terutama untuk pabrik gula berkapasitas besar seperti PG. Bungamayang. Jika tidak akurat maka pasok tebu dari petani akan lebih berorientasi kepada bobot tebu yang relatif lebih mudah dicapai, diamati dan diukur, namun tidak mendukung perolehan gula maksimal. Kemajuan teknologi merupakan instrumen utama dalam pemanfaatan sumberdaya pertanian sehingga produk (tebu) memenuhi syarat mutu yang diharapkan (Ibrahim, Hasanudin, dalam Anonimus, 2004). Salah satu upaya mengatasi permasalahan tersebut adalah dengan melakukan analisis tebu melalui: (1) sampling tebu individu, (2) sampel dinilai berdasarkan kualitas tebu individu, (3) faktor pabrik dinilai berdasarkan kristal nyata yang dihasilkan dalam rentang waktu tertentu. Metoda 
pengukuran rendemen yang lebih akurat dilakukan melalui: (1) sampling tebu individu di atas truk/lori menggunakan Core Sampler (CS), (2) pengukuran kualitas dan kuantitas nira individu didekati dengan kristal NPP individu \% tebu, dan (3) faktor pabrik didekati dengan Faktor Kristal (yaitu Faktor Rendemen dibagi KNPP \% tebu dikalikan 100). Untuk mempercepat hasil pengukuran Pol tebu individu digunakan alat NIR. Bahri (2013) mengemukakan bahwa teknologi yang diharapkan mampu menetapkan rendemen tebu secar individual dan berkeadilan adalah teknologi penetapan rendemen tebu individual menggunakan CS.

Kawalan yang dilakukan pada tahun 2014 difokuskan pada: (1) konsep aplikasi sistem penetapan rendemen individu dengan CS pada tahap pertama (transisi), dan (2) sosialisasi kepada petani tebu untuk memberikan pemahaman tentang sistem penetapan rendemen individu serta menggali respon petani terhadap sistem penetapan rendemen individu dengan dukungan CS. Proses diseminasi teknologi penting untuk dikaji untuk memastikan teknologi dapat diadopsi oleh pengguna. Keluaran dari proses diseminasi CS ini adalah sebagai berikut: (1). tersusunnya konsep aplikasi sistem penetapan rendemen individu dengan CS yang sesuai untuk diterapkan pada tahap pertama (transisi), (2). Tersosialisasikan sistem penentuan rendemen dengan menggunakan CS untuk menetapkan rendemen individu secara cepat, akurat, dan dapat menghargai prestasi individu petani tebu.

\section{METODE PENELITIAN}

Landasan teori yang digunakan adalah mikrososiologi yang merupakan penjelasan mengenai kehidupan sosial dan struktur sosial (antara petani yang akan mengadopsi sistem CS dan PG Bungamayang serta P3GI yang akan melakukan diseminasi) berada pada level individual atau menekankan pada interaksi diantara kedua pihak (Usman S, 2012). Rancangan, ruang lingkup, dan prosedur kerja kajian diseminasi ini adalah sebagai berikut:

1. Sosialisasi kepada petugas dan petani tebu di PG Bungamayang sebelum musim giling (tanggal 26-27 Maret 2014), dengan materi: (a) Pentingnya mengoptimalkan sistem TMA (Tebang Muat Angkut), (b) Pengukuran rendemen individu menggunakan sistem CS, (c) Gambaran budidaya tebu yang optimal untuk mendukung penerapan penentuan rendemen dengan sistem CS. Kuesioner untuk mengetahui tingkat penyerapan materi dibagikan kepada peserta sosialisasi sebelum dan setelah sosialisasi dilakukan.

2. Penyusunan konsep aplikasi sistem penetapan rendemen individu dengan CS yang sesuai untuk diterapkan pada tahap pertama (transisi), dengan tujuan mempersiapkan mental petani dari sistem penetapan rendemen yang diterapkan sebelumnya (rendemen sama untuk semua individu) menuju sistem penetapan rendemen individu yang menghargai prestasi individu. Masa transisi ini diperlukan dalam proses diseminasi karena secara umum diseminasi adalah penerapan komunikasi perspektif psikologis yang bersifat eksperimental (Fisher,B. A, 1986).

3. Pengawalan pelaksanaan sistem CS awal musim giling, meliputi: (a) Kesepakatan dengan petani tebu untuk uji coba sistem CS pada periode pertama musim giling, yang diperlukan karena adanya dua pihak (petani tebu dan PG) yang berintertransaksional yang menjadi pusat sistem tanggungjawab suatu komunitas (Greif, A, 2006); (b) Sosialisasi kepada petani pada periode pertama musim giling selama periode uji coba untuk memberikan pemahaman lebih baik kepada petani terkait keuntungan maupun konsekuensi pelaksanaan sistem CS, tanggal $25-26$ April 2014. Materi sosialisasi sebagai berikut: Pentingnya mengoptimalkan sistem TMA (Tebang Muat Angkut), Pengukuran rendemen individu menggunakan sistem CS, Sistem payment (pembayaran) kepada petani, Transparansi pengukuran rendemen, Display operasional sistem CS, Gambaran budidaya tebu yang optimal untuk mendukung penerapan penentuan rendemen dengan sistem CS. Kuesioner diberikan kepada peserta sosialisasi sebelum dan setelah sosialisasi dilakukan; (c) Kesepakatan dengan petani pada akhir periode pertama musim giling tentang keputusan pelaksanaan sistem CS sebagai dasar payment masa selama giling tahun 2014; (d) Kesepakatan sistem CS sebagai dasar payment kepada petani pada musim giling tahun 2014, melalui kuesioner untuk seluruh Ketua Kelompok 
Tani melihat pemahaman di tingkat Ketua Kelompok Tani. Bentuk hubungan dominan antara petani, koordinator dan ketua kelompok perlu mendapat perhatian dalam mengkaji proses diseminasi dimana petani merupakan salah satu komponen dalam hubungan tersebut (Wolf, Eric R, 1985).

4. Evaluasi setelah aplikasi CS di PG. Bungamayang tanggal 25 - 27 Juni 2014 di tingkat koordinator, kelompok tani dan petani tebu setelah memasuki periode ke 4 , dilakukan dengan metode Focus Group Discussion (FGD) di setiap wilayah TR dilaksanakan 2 kelompok diskusi (FGD), sehingga secara keseluruhan dilakukan 4 kali FGD dengan 4 kelompok berbeda. Metode FGD dilakukan dengan cara beberapa orang melakukan diskusi secara fokus dan mendalam mengenai obyek tertentu. Data hasil diskusi dikumpulkan untuk dipakai dalam proses kajian selanjutnya (Umar, Husein, 2002).

\section{HASIL DAN PEMBAHASAN}

\section{Sosialisasi kepada petugas dan petani tebu di PG Bungamayang sebelum musim giling}

Sosialisasi dilakukan dengan beberapa langkah yaitu pembuatan konsep sistem penetapan rendemen individu CS, sosialisasi tahap awal, Sosialisasi kepada petani pada periode pertama musim giling, Persiapan operasional penetapan rendemen individu dengan sistem CS, Sistem administrasi untuk pelaksanaan CS sebagai dasar payment kepada petani pada seluruh periode giling,

Pembuatan Konsep awal sistem penetapan
rendemen individu dengan CS di PG.
Bungamayang
$\quad$ Konsep awal sistem penetapan rendemen individu dengan CS di PG. Bungamayang dilakukan berdasarkan hasil kajian yang telah dilakukan oleh P3GI pada Tahun 2010-2011. Kualitas bahan baku yang belum merata sepanjang musim giling, menyebabkan kurva rendemen berbentuk kuadratik (gambar 1). Kurva menunjukkan pada awal giling rendemen rendah karena bahan baku yang belum memenuhi syarat dan pada akhir giling rendemen tebu rendah karena bahan baku tinggal sisa-sisa dengan kualitas rendah.

Perkiraan rendemen per individu (truk) dapat dihitung dari analisis tebu yang diambil sampelnya. Nilai rendemen belum murni karena tercampur unsur kinerja pabrik yang dipengaruhi waktu giling. Oleh karena itu rendemen per individu perlu dikoreksi terhadap waktu giling tersebut.

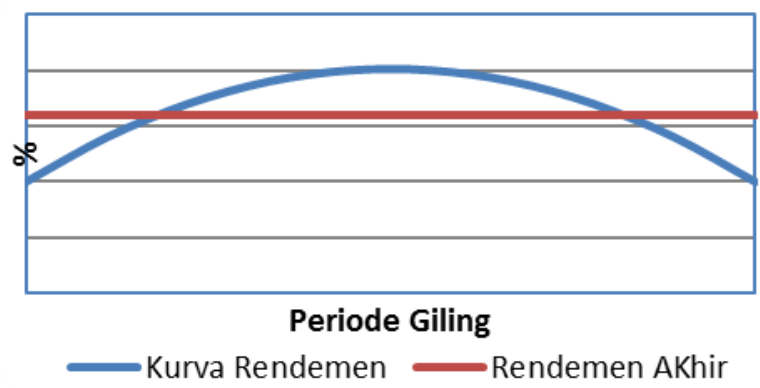

Gambar 1. Kurva rendemen kuadratik sepanjang musim giling.

Nilai koreksi dikaitkan dengan nilai rendemen akhir, namun karena nilai rendemen akhir ini diketahui setelah semua kebun selesai ditebang, maka penentuan rendemen individu diusulkan dalam dua tahap, yaitu: (1) rendemen sementara untuk mengakomodasi keinginan pembayaran hasil giling yang cepat dan (2) kekurangan rendemen yang ditambahkan setelah rendemen akhir diperoleh. Prosedur pengukuran dan perhitungan rendemen individu menggunakan CS sebagai berikut: (a). Tebu dalam truk sesuai jadwal diangkut ke emplasemen CS, (b). Dibor dengan kemiringan $60^{\circ}$, dicacah dengan shredder, diperah dengan hydraulic press, sampel nira yang dihasilkan dianalisis. Diagram alur pengambilan contoh tebu adalah sebagai berikut: 


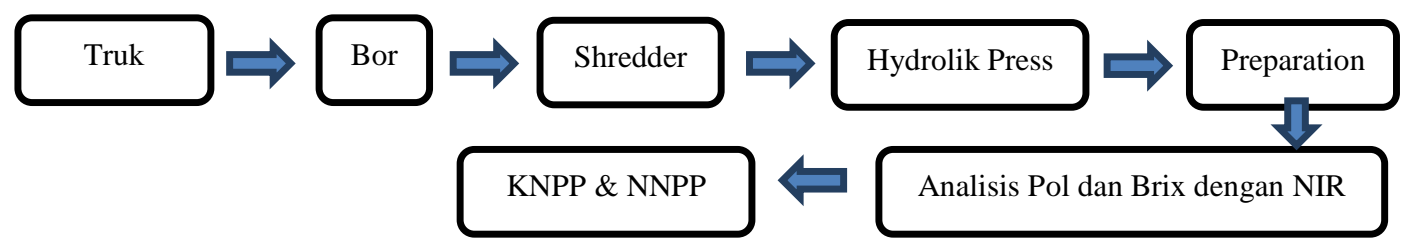

Gambar 2. Alur penerbitan data KNPP dan NNPP

Dari proses analisa dihasilkan data Kadar nira perahan pertama (KNPP) dan Nilai Nira Perahan Pertama (NNPP) individu untuk truk dimaksud. Dimana NNPP adalah potensi gula kristal dalam nira hasil setelah di press (dalam \%) dan KNPP adalah jumlah nira hasil press (dalam \%). Selanjutnya truk menuju timbangan untuk mendapatkan data bobot tebu per truk. Dengan demikian Faktor Kristal (FK) harian dapat dihitung yaitu ratio antara hasil kristal nyata pada hari itu dibagi dengan perkiraan kristal berdasarkan data CS (ditentukan harian, mingguan atau 15 harian).

Perkiraan Rendemen individu (belum terkoreksi) pada suatu periode dihitung sebagai berikut:

$$
\mathbf{R}_{\mathbf{i j}}=\mathbf{K N P P}_{\mathbf{i j}} * \mathbf{N N P P}_{\mathbf{i j}} * \mathbf{F K}_{\mathbf{i}} * \mathbf{1 0}^{-\mathbf{2}}
$$

$\left(\mathrm{R}_{\mathrm{ij}}=\right.$ perkiraan rendemen individu ke $\mathrm{j}$ yang digiling pada periode ke-i)

Rumus rendemen individu sementara setiap truk yang dapat digunakan untuk pembayaran bagi hasil yang pertama dihitung sebagai berikut:

$$
\mathbf{R S}_{\mathbf{i j}}=\left(\mathbf{R}_{\mathbf{0}}-\left(\mathbf{R}_{\mathbf{i}}-\mathbf{R}_{\mathbf{i j}}\right)\right)
$$

$\mathrm{RS}_{\mathrm{ij}}$ : Rendemen sementara individu (truk) ke-j pada periode ke-i untuk pembayaran bagi hasil yang pertama

$\mathrm{R}_{0}$ : Rendemen dasar yang disepakati sebagai acuan perhitungan rendemen. Diusulkan menggunakan $85 \%$ dari rata-rata rendemen 3 tahun terakhir atau $70 \%$ dari rendemen RKAP

$\mathrm{R}_{\mathrm{i}}$ : Rendemen real pada periode ke-i. Diusulkan satu minggu.

$\mathrm{R}_{\mathrm{ij}}$ : Perkiraan rendemen individu ke $\mathrm{j}$ yang digiling pada periode ke-i

Rumus tambahan rendemen setelah selesai giling bagi setiap individu yang dapat digunakan untuk pembayaran bagi hasil yang kedua adalah

$$
\Delta \mathbf{R}=\left(\mathbf{R}_{\mathbf{A}}-\mathbf{R}_{\mathbf{0}}\right)
$$

$\mathrm{R}_{\mathrm{A}}$ : Rendemen akhir PG a. Sosialisasi kepada petani pada periode pertama musim giling

Sosialisasi kepada petani tebu selama periode uji coba (periode pertama musim giling) untuk memberikan pemahaman lebih baik kepada petani terkait keuntungan maupun konsekuensi pelaksanaan sistem penetapan rendemen individu dengan CS, tanggal $26-27$ April 2014. Hasil sosialisasi secara rinci dapat dilihat pada Lampiran 1. Materi pada kegiatan ini adalah pemahaman sistem CS. Sosialisasi dilaksanakan secara sampling di 2 (dua) lokasi, yaitu Sukamaju dan Mulyorejo, menunjukkan bahwa petani dapat memahami dengan baik bahwa CS adalah alat untuk mengambil contoh tebu secara individu, dan pemahaman terhadap penentuan rendemen dengan sistem CS meningkat. Dalam proses diseminasi prediksi terhadap perilaku dan sikap konsumen atau sasaran diseminasi adalah penting. Sutisna (2001) mengemukakan faktor yang mempengaruhi prediksi perilaku oleh sikap, antara lain: (a) Keterlibatan konsumen atau sasaran diseminasi, (b) Pengukuran sikap melalui pertanyaan sikap konsumen, (c) Pengaruh orang lain, (d) Faktor situasional, dan (e) Kekuatan sikap konsumen terhadap obyek inovasi yang didiseminasikan. Dalam melakukan diseminasi suatu teknologi perlu diketahui hambatan-hambatan yang dimiliki petani yaitu: pengetahuan terhadap teknologi, motivasi mengubah perilaku, sumberdaya (modal dan sarana produksi), wawasan untuk memdapatkan sumberdaya yang diperlukan, kekuasaan menguasai sumberdaya, jaringan sosial, dan wawasan hubungan kekuasaan dalam masyarakat. Oleh sebab itu penyuluhan harus dilakukan sebagai proses secara sistematis sehingga petani mampu mengambil keputusan, mengevaluasi, dan meningkatkan keterampilannya (A. W. Van den Ban dan H.S. Hawkins, 1999). Hasil uji coba sistem CS disampaikan kepada petani dan diambil 
kesepakatan, tentang penentuan rendemen dengan CS sebagai dasar bagi hasil gula kepada petani untuk tahun giling 2014. Jumlah petani TR binaan PG. Bungamayang tahun 2014 sebanyak 5.616 orang dengan jumlah kelompok tani 694 orang. Hasil uji coba penentuan rendemen dengan sistem CS pada tanggal 22 April s/d 15 Mei 2014 untuk TR dapat dilihat pada Tabel 1. Dilihat dari jumlah truk yang masuk, persentase yang paling tinggi adalah pada kisaran rendemen $7,5-<8,50 \%$ sebanyak 1.187 truk.

Tabel 1. Jumlah truk TR pada beberapa variasi kisaran rendemen sistem CS

\begin{tabular}{ccccc}
\hline $\begin{array}{c}\text { Variasi rendemen } \\
\text { tebu TR }(\boldsymbol{\%})\end{array}$ & $\begin{array}{c}\text { Jumlah truk } \\
\text { (buah) }\end{array}$ & $\begin{array}{c}\text { Jumlah truk } \\
(\boldsymbol{\%})\end{array}$ & $\begin{array}{c}\text { Jumlah petani } \\
\text { (orang) }\end{array}$ & $\begin{array}{c}\text { Jumlah petani } \\
(\boldsymbol{\%})\end{array}$ \\
\hline$<6,5$ & 563 & 11,4 & 1 & 0,2 \\
\hline $6,5-<7,0$ & 549 & 11,1 & 39 & 6,2 \\
\hline $7,0-<7,5$ & 1.037 & 20,9 & 163 & 25,9 \\
\hline $7,5-<8,0$ & 1.187 & 24,0 & 259 & 41,1 \\
\hline $8,0-<8,5$ & 856 & 17,3 & 122 & 19,4 \\
\hline$>8,5$ & 755 & 15,3 & 46 & 7,3 \\
\hline Jumlah & 4.947 & 100 & 630 & 100 \\
\hline
\end{tabular}

Tabel 1 di atas juga menunjukkan pada periode 1 musim giling lebih dari $90 \%$ petani tebu memperoleh rendemen $\geq 7 \%$, variasi rendemen individu sangat besar karena perbedaan kualitas tebu. Manfaat sistem CS ini membangkitkan semangat para petani untuk melakukan teknis budidaya standar yang direkomendasikan oleh PG, dan mengirimkan tebu MBS (Manis, Bersih, dan Segar). Petani yang sudah balik kualitas tebangnya memang layak dihargai kerja kerasnya dan petani yang belum baik akan termotivasi untuk menjadi lebih baik. Keuntungan bagi PG. Bungamayang adalah memperoleh kualitas bahan baku TR yang lebih baik, difusi teknologi budidaya kepada petani lebih mudah dan sistem penataan TMA (Tebang Muat Angkut) optimal lebih mudah dilaksanakan.

b. Sistem administrasi untuk pelaksanaan CS sebagai dasar payment kepada petani pada seluruh periode giling

Apabila sistem penetapan rendemen individu dengan CS ini diterapkan sebagai dasar pembayaran (payment) kepada petani selama musim giling tahun 2014, maka sistem administrasi harus ditata sedemikian rupa agar tidak terjadi permasalahan di belakang hari. Terkait persetujuan di tingkat petani dilakukan juga revisi dokumen kontrak dan pendelegasian wewenang individu petani kepada Ketua Kelompok Tani. Tahapan dalam sistem administrasi pelaksanaan CS meliputi:
Persetujuan di tingkat petani, Revisi dokumen kontrak, Pendelegasian wewenang petani kepada Ketua Kelompok Tani, Pendelegasian wewenang petani kepada Ketua Kelompok diperlukan karena fungsi kelompok, yaitu: (a) Hubungan sosial, kemampuan kelompok memelihara hubungan sosial para anggota kelompok, (b) Pendidikan, kelompok secara formal dan informal mempertukarkan pengetahuan, (c) Persuasi, saling mempersuasi antara anggota dan ketua kelompok untuk melakukan atau tidak melakukan sesuatu, (d) Problem solving, kelompok dicerminkan dengan kegiatan memecahkan persoalan dan membuat keputusan (Bungin, 2007).

c. Evaluasi setelah pelaksanaan CS di PG Bungamayang

Manfaat evaluasi dalam proses diseminasi adalah : (a) Agar agent pelaku diseminasi setiap saat dapat mengambil keputusan dan melakukan tindakan terbaik, (b) Memeriksa program diseminasi dan mengupayakan perbaikan yang diperlukan, (c) Menimbulkan rasa aman bagi pelaku diseminasi karena mengetahui perkembangan kegiatan dalam proses diseminasi, (d) Dapat melakukan hubungan masyarakat dan mempublikasikan hasil proses diseminasi, (e) Tumbuh sikap profesionalisme dengan evaluasi ilmiah yang dilakukannya (Anonimus, 2001). Evaluasi pelaksanaan CS dilakukan tanggal 23 - 29 Juni 2014. dengan metode Focus 
Group Discusion (FGD). Di setiap wilayah TR dilaksanakan 2 kelompok diskusi (FGD), keseluruhan dilakukan 4 kali FGD pada 4 kelompok berbeda.

Dari 530 kuesioner yang diisi oleh Ketua Kelompok Tani tebu dari 24 desa di wilayah PG. Bungamayang, diperoleh data respon petani tebu terhadap rendemen individu dari hasil pengambilan contoh dengan menggunakan CS. Data menunjukkan hampir $50 \%$ dapat menerima hasil rendemen yang dicapai, jumlah anggota kelompok yang menolak capaian rendemen CS menurun. Tampak pada Tabel 2 bahwa kelompok yang jumlah anggotanya hanya $25 \%$ atau kurang mau menerima rendemen CS sebesar $1,88 \%$.

Tabel 2. Respon anggota kelompok terhadap perolehan rendemen

\begin{tabular}{clc}
\hline No. & \multicolumn{1}{c}{ Parameter } & Respon (\%) \\
\hline 1 & Semua anggota kelompok dapat menerima rendemen yang dicapai & 48,68 \\
2 & Hanya 75\% dari mereka dapat menerima & 20,57 \\
3 & Hanya 50\% dari mereka dapat menerima & 7,92 \\
4 & Hanya 25\% dari mereka dapat menerima & 0,94 \\
5 & Kurang dari 25\% dari mereka dapat menerima & 0,94 \\
6 & Tidak menjawab & 20,95 \\
\hline \multicolumn{2}{c}{ Jumlah } & 100 \\
\hline
\end{tabular}

Tabel 3. Alasan responden mau menerima rendemen dari hasil pengambilan contoh menggunakan CS

\begin{tabular}{clc}
\hline No. & \multicolumn{1}{c}{ Alasan Menerima } & Respon (\%) \\
\hline 1 & Sesuai dengan budidaya tebu yang dikerjakan dan fisik tanaman & 41,51 \\
2 & Pasrah & 10,75 \\
3 & Tidak berani mengajukan protes & 2,83 \\
4 & Tidak ingin ribut & 1,70 \\
5 & Lebih tinggi daripada rendemen rata-rata tahun sebelumnya & 21,13 \\
6 & Tidak menjawab & 22,08 \\
\hline & & Jumlah \\
\hline
\end{tabular}

Sebesar 62,64\% responden dapat menerima capaian rendemen dengan alasan positif, yaitu: (a) sudah sesuai dengan budidaya tebu yang dilakukan dan hasil fisik tanaman tebu yang dipanen dan (b) rendemen yang diperoleh sudah lebih tinggi daripada rendemen rata-rata yang diterima tahun sebelumnya. Responden yang menerima dengan alasan sudah sesuai dengan budidaya tebu yang dilakukan dan hasil fisik tanaman adalah sebesar $41,51 \%$, sedangkan yang memberikan alasan bahwa rendemen yang dicapai di atas rata-rata rendemen pada tahun sebelumnya adalah $21,13 \%$. Responden yang menerima namun dengan alasan negatif, yaitu: pasrah, tidka berani mengajukan protes dan tidak ingin ribut sebesar 15,28\%. Meskipun persentasenya di bawah alasan positif, tetapi kelompok ini perlu dicermati untuk tidak semakin berpotensi menurun motivasi menanam tebunya atau semakin pasif dalam meningkatkan mutu bahan baku yang dipasok ke PG. Bungamayang. Pemberian pemahaman melalui sosialisasi, penjelasan tentang mutu bahan baku, mutu budidaya tebu yang dilakukan dan sistem kerja CS serta sistem analisa rendemen individu sebaiknya dilakukan secara rutin kepada para petani tebu khususnya kelompok yang memberikan alasan negatif terhadap capaian rendemennya (tabel 3). 
Tabel 4. Alasan responden menolak rendemen dari hasil pengambilan contoh menggunakan CS

\begin{tabular}{clc}
\hline No. & \multicolumn{1}{c}{ Alasan Menerima } & Respon $(\%)$ \\
\hline 1 & Tidak sesuai dengan budidaya tebu yang dikerjakan dan fisik tanaman tebu & 29,25 \\
& yang dihasilkan & \\
2 & Rendemen rendah karena pengaruh iklim, bukan kesalahan petani & 13,40 \\
3 & Pabrik sering rusak sehingga rendemen rendah & 24,34 \\
4 & Tidak pernah dilakukan sosialisasi tentang perolehan rendemen & 2,08 \\
5 & Lebih rendah daripada rendemen tahun sebelumnya & 0,75 \\
6 & Ada kecurigaan permainan atau rekayasa rendemen oleh petugas & 9,43 \\
7 & Tidak menjawab & 20,75 \\
\hline & & 100 \\
\hline
\end{tabular}

Penolakan terhadap rendemen yang diperoleh dari hasil pengambilan contoh dengan CS terutama disebabkan oleh rasa tidak puas karena merasa telah melaksanakan pekerjaan budidaya tebu dengan baik $(29,25 \%)$. Alasan kedua adalah sering terjadi kerusakan pada pabrik (24,24\%). Meskipun jumlah responden yang menolak capaian rendemen ini kurang dari 5\%, tetapi hasil penelitian ini dapat menjadi bahan perbaikan sistem penerapan CS di tingkat TR di masa datang. Dugaan terjadinya ketidakpuasan terhadap rendemen dapat terjadi karena posisi pengambilan contoh tebu yang tidak mewakili (atas, tengah, bawah) semua batang tebu di atas truk yang dikirim ke PG. Perlu periksa silang pengamatan tebu yang dipasok ke PG dengan parameter kotoran, sogolan dan unsurunsur yang diduga dapat menurunkan rendemen tebu (tabel 4).

Tabel 5. Cara ketua kelompok menyampaikan penjelasan tentang rendemen hasil CS yang diperoleh kepada anggota kelompok

\begin{tabular}{clc}
\hline No. & \multicolumn{1}{c}{ Cara Penjelasan } & Respon (\%) \\
\hline 1 & Rendemen harus diterima apa adanya karena sesuai mutu budidaya tebunya & 22,64 \\
2 & Jika ingin rendemen lebih tinggi harus dilakukan perbaikan mutu budidaya & 38,49 \\
& tebu & \\
3 & Silahkan protes ke PG & 1,32 \\
4 & Dijelaskan proses pengambilan sampel tebu menggunakan CS & 5,85 \\
5 & Dijelaskan prinsip tentang rendemen individu & 8,87 \\
6 & Tidak menjawab & 22,83 \\
\hline & Jumlah & 100 \\
\hline
\end{tabular}

Ketua kelompok tani tebu menyampaikan penjelasan tentang perolehan rendemen kepada anggota kelompok, telah dilakukan dengan cara dan penjelasan yang benar yaitu memotivasi petani tebu untuk memperbaiki budidaya tebunya jika ingin mendapatkan rendemen lebih tinggi $(38,49 \%)$. Jawaban ini melengkapi jawaban bahwa rendemen harus diterima sesuai mutu budidaya tebunya (22,64\%). Penjelasan tersebut dikatakan sudah cukup memadai dengan melihat bahwa hanya $1,32 \%$ kelompok yang menjawab dengan mempersilahkan petani mengajukan protes ke PG. Selanjutnya kelompok dapat dimotivasi dengan menjelaskan tentang proses pengambilan sampel tebu dengan menggunakan CS dan prinsip tentang rendemen individu (tabel 5). Data tentang jumlah anggota kelompok memudahkan cara menyampaikan penjelasan kepada anggota kelompok. Di PG. Bungamayang setiap kelompok rata-rata maksimal 20 orang petani tebu. Jumlah ini seharusnya tidak menyulitkan penyampaian informasi secara efektif dan efisien.

\section{KESIMPULAN}

Pada awal giling telah disepakati oleh petani tebu bahwa akan dilaksanakan ujicoba penentuan rendemen individu dengan CS. Hasil evaluasi ujicoba adalah rendemen menggunakan sistem CS persentase tertinggi adalah rendemen $7,5-<8 \%(24 \%)$. Seluruh koordinator kelompok tani menyetujui rendemen individu dan hasil uji coba sistem CS diaplikasikan sebagai dasar pembayaran perhitungan bagi hasil kepada petani tebu pada musim giling tahun 2014. Respon petani pada tahap penerapan CS, 63,96\% menerima hasil rendemen yang dicapai, $48,68 \%$ dapat 
menerima hasil rendemen yang dicapai dengan positif: (a) Sudah sesuai dengan budidaya tebu yang dilakukan dan fisik tanaman tebu yang dipanen, dan (b) Rendemen yang diperoleh lebih tinggi daripada rendemen rata-rata yang diterima tahun sebelumnya. Penerimaan namun dengan alasan negatif yaitu: pasrah, tidak berani mengajukan protes dan tidak ingin ribut adalah sebesar $15,28 \%$. Penolakan terhadap rendemen hasil CS sebesar 1,88\%, dengan alasan, yaitu: (a) karena merasa telah melaksanakan pekerjaan budidaya tebu dengan baik, (b) sering terjadi kerusakan pada pabrik, dan responden yang tidak menjawab 18,88\%. Cara ketua kelompok menyampaikan penjelasan rendemen hasil CS dilakukan dengan benar yaitu memotivasi petani tebu untuk memperbaiki budidaya tebunya jika ingin mendapatkan rendemen lebih tinggi $(38,49 \%)$ dan rendemen diterima sesuai mutu budidaya tebunya $(22,64 \%)$. Komunikasi yang dilakukan Ketua Kelompok dan anggota kelompok cukup bagus, 49,6\% Ketua Kelompok Tani telah menyampaikan hasil rendemen kepada anggotanya. Berdasarkan analisis hasi pembahasan dapat disimpulkan bahwa sistem CS layak untuk diterapkan untuk menjadi solusi permasalahan dalam penentuan rendemen secara individu.

\section{UCAPAN TERIMA KASIH}

Ucapan terima kasih kami sampaikan kepada seluruh Direksi PTP Nusantara VII yang telah mempercayakan pekerjaan pengawalan CS ini kepada Pusat Penelitian Perkebunan Gula Indonesia (P3GI). Ucapan terima kasih juga kami sampaikan kepada seluruh jajaran PG. Bungamayang yang telah bekerjasama dengan baik selama pengawalan ini berlangsung sehingga kegiatan pengawalan CS dapat selesai dengan hasil sangat baik.

\section{DAFTAR PUSTAKA}

Anonimus, 2001. Penyuluhan Pertanian, Yayasan Pengembangan Sinar Tani, Jakarta, hal: 361-362.

Arifin, Bustanul, 2004, Analisis Ekonomi Pertanian Indonesia, Penerbit Buku Kompas, Jakarta, hal: 222.
A.W. van den Ban dan H. S. Hawkins, 1999, Penyuluhan Pertanian, Kanisius, Yogyakarta, hal: 26-29.

Bahri, 2013, Teknologi core sampler untuk penetapan rendemen tebu individual, majalah penelitian gula. Vol 49, Desember 2013, P3GI, Pasuruan, hal: 4859.

Bungin, H. M. Burhan, 2007, Sosiologi Komunikasi, Kencana Prenada Media Group, Jakarta, hal: 270-271.

Fisher, B. Aubrey, 1986, Teori-Teori Komunikasi, PT. Remaja Rosdakarya, Bandung, hal: 219-220.

Greif, Avner, 2006, Institutions and The Path To The Modern Economy, Cambridge University Press, Cambridge, hal: 310.

Ibrahim, Hasanudin, 2004, Membangun Sistem Produksi Perkebunan Berdasarkan Kompetensi, dalam Anonimus, 2004, Rekonstruksi dan Restrukturisasi Ekonomi Pertanian, PERHEPI, Jakarta, hal; 219.

Kartasapoetra, G, Kartasapoetra, R. G, dan Kartasapoetra, A. G, 1986, Marketing Produk Pertanian dan Industri, Bina Aksara, Jakarta, hal: 112-113.

Migdal, Joel S, 1974, Peasants, Politics, and Revolution, Princeton University Press, New Jersey, hal: 237.

Mosher, A.T., 1984, Menggerakkan dan Membangun Pertanian-Syarat-syarat Pokok Pembangunan dan Modernisasi, 1965, C.V. Yasaguna, Jakarta, hal: 34-35.

Sunyoto, Usman, 2012, Sosiologi, Sejarah, Teori, dan Metodologi, Pustaka Pelajar, Yogyakarta, hal: 56.

Sutisna, 2001, Perilaku Konsumen dan Komunikasi Pemasaran, PT Remaja Rosdakarya, Bandung, hal: 116-117.

Umar, Husein, 2002, Metode Riset Komunikasi Organisasi, PT. Gramedia Pustaka Utama, Jakarta, hal: 91.

Wolf, Eric R, 1985, Petani Suatu Tinjauan Antropologis, C.V. Rajawali, Jakarta, hal: 159. 